\title{
Performance Appraisal of Employees in IT Industries in Chennai City
}

\begin{abstract}
Performance assessment is a part of career growth. Performance appraisals a required and beneficial process, which offers annual feedback to staff members about job efficiency and career guidance. The performance assessment is envisioned to be a fair and balanced assessment of an employee's performance. This study was primarily focuses to identify the effectiveness performance evaluation system in the organisation. The study will provide the effectiveness of performance assessment used in the organisation and help in improving the system accordingly. The suggestions of the employees are also analysed. The result indicates that effectiveness of performance evaluation in the organisation shows that some improvisation have to be done with the present system. The present system used to measure the performance of the employees is still have to be improved by adding some more attribute.
\end{abstract}

S. Anitha

Keywords: Performance Appraisal, IT employees, evaluation and system.

\section{INTRODUCTION}

$\mathrm{P}$ erformance appraisal is also known as employees evaluation, is a technique by which the job performance of an employee is evaluated. Performance assessment is a part of career growth. Performance appraisals a required and beneficial process, which offers annual feedback to staff members about job efficiency and career guidance. The performance assessment is envisioned to be a fair and balanced assessment of an employee's performance.

The human disposition to judge can create thoughtful motivational, ethical and legal difficulties in the workplace. Without a planned assessment system, there is little chance of safeguarding that the judgments made will be lawful, fair, impregnable and accurate.

According to contemporary Appraisal, the Performance evaluation may be defined as a organized formal interface between a subordinate and supervisor, that typically takes the form of a intervallic interview, in which the work performance of the subordinate is observed and discussed, with a view to ascertaining faintness and strengths as well as chances for improvement and skills development.

Performance reviews are regular reviews of workers performance within organizations. Generally, the purposes of a performance appraisal are to Give comment on performance to employees, find employee training needs, Document standards used to allocate organizational rewards, it also form a basis for personnel such as salary increases, promotions, disciplinary actions, etc. Performance evaluation provides the opportunity for organizational analysis and development, facilitates decisions communication between employee and administrator, authenticate selection techniques and human resource strategies to meet federal and equal employment opportunity. Thus it is necessary to have the performance assessment system in every organisational requirements.

\section{OBJECTIVES OF THE STUDY}

- To evaluate the effectivness of performance appraisal system in the organisation.

- To identify attributes which is to be further considered for the measurement of performance evaluation.

- To get the opinion of the employees to improve the present performance appraisal system.

\section{SCOPE OF THE STUDY}

To identify the effectiveness performance evaluation system in the organisation. The study will provide the effectiveness of performance assessment used in the organisation and help in improving the system accordingly. The suggestions of the employees are also analysed.

\section{LIMITATIONS OF THE STUDY}

The study suffers the following limitations. The study is restricted to one company thus the findings cannot be generalized. As the industry has some unique characteristics, the organisation cannot be a representative of all industry across the country and outside.

Another important aspect of concern which hinders as a major limitation to the project is that the present system and its statistics has not been provided in record but made as an assumption by the feedback from the HR department.

\section{RESEARCH METHODOLOGY}

\section{A. Research design}

The research design adopted for this study is descriptive analysis. The descriptive analysis studies are those studies which are concerned with telling the characteristics of a specific individual, or of a group. The studies concerned with precise predictions, with narration of facts \& characteristics concerning individual, group or situation are all examples of descriptive research analysis. 


\section{B. Sampling Technique}

Probability Sampling: Sample design is the basis within which the sampling has to be conceded out. Sampling is the method of choosing a group from population to signify the population. Sample is the quantity of the population, which acts as a illustrative of the population through its character and nature.

Method of Data Collection: Primary and secondary data are collected. Primary data was collected with the help of questionnaire and personal interview schedule. Secondary data were collected by referring company handbook, other article about the company, websites and magazines.

Sample size and area of data collection - From the population size of 1100, among that 700 are working in the middle cadre, a sample of 100 has been selected for the study by using the simple random sampling. This sample size is taken from the middle cadre.

Tools of Analysis: Data is tabulated by means of simple Percentages, cross tabulation analysis.

Statistical Tools: The data collected were analyzed with reference to the specific objectives of the study and the following statistical tools were used in the study.
a. Chi- Square test.
b. Cross tabulation
c. Simple percentage analysis.

\section{RESULTS AND DISCUSSION}

\section{A. Quality of Work}

The table. 1 indicates the respondents on the effectiveness of quality of work and percentage of the respondents is analysis. effectiveness of quality of work

\begin{tabular}{|c|c|c|}
\hline Particulars & Frequency & Percentage \\
\hline Strongly Agree & 23 & 23 \\
\hline Agree & 63 & 63 \\
\hline Neutral & 14 & 100 \\
\hline Total & 100 & 100 \\
\hline
\end{tabular}

From the table.1, we can infer that $63 \%$ of the respondents are agreeing with effectiveness of the quality of work, $23 \%$ have strongly agreed and $14 \%$ are neutral with its effectiveness. Thus we infer that the quality of work considered for the measurement of performance among the employees are very high because the effectiveness of work quality is considered important in the organisation.

\section{B. Demographic Variable Vs Effectiveness Of Performance Evaluation}

To analyze the influence of age factors on leading to performance evaluation, the chi-square test is performed at $5 \%$ significant level and the following hypothesis is formulated.

Hypothesis: Age does not influence on effectiveness of performance evaluation with respect to respondents.

The above hypothesis is tested using chi-square analysis and the result is summarized below.
Table - 1: Distribution of respondents on the basis of

Influence of age on factors leading to effectiveness of performance evaluation

Table - 2: Age vs Effectiveness of Performance Evaluation of Respondents

\begin{tabular}{|c|c|c|c|}
\hline Factors & $\begin{array}{c}\text { Chi-square } \\
\text { value }\end{array}$ & $\begin{array}{c}P \\
\text { Value }\end{array}$ & Result \\
\hline Communication & 17.998 & 0.035 & Disagree \\
\hline Teamwork & 12.389 & 0.192 & Agree \\
\hline Reliability & 17.984 & 0.116 & Agree \\
\hline Responsibility & 12.725 & 0.175 & Agree \\
\hline $\begin{array}{l}\text { Interpersonal } \\
\text { relationship }\end{array}$ & 12.657 & 0.179 & Agree \\
\hline Interpersonal skills & 19.667 & 0.020 & Disagree \\
\hline Flexibility & 22.387 & 0.033 & Disagree \\
\hline Strategic thinking & 17.773 & 0.123 & Agree \\
\hline Fiscal responsibility & 15.554 & 0.077 & Agree \\
\hline Ability & 25.679 & 0.002 & Disagree \\
\hline $\begin{array}{l}\text { Challenging } \\
\text { formalities }\end{array}$ & 19.198 & 0.084 & Agree \\
\hline Goal oriented & 16.362 & 0.012 & Disagree \\
\hline Ethical value & 15.275 & 0.084 & Agree \\
\hline Judgment & 30.882 & 0.002 & Disagree \\
\hline Standardisation & 7.477 & 0.825 & Agree \\
\hline
\end{tabular}

As $\mathrm{P}$ value is less than the table $\mathrm{H} 0$ is rejected at 0.05 level of significance. So it is inferred that people of all ages desire the same type of quality of work life.

From the above table it is inferred that the demographic variable age has no significant inference on the factors like teamwork, Reliability, Responsibility, Interpersonal relationship, Strategic thinking, Fiscal responsibility, Challenging formalities, Ethical value, Standardisation. The demographic variable age has significant inference on the factors like Communication, Interpersonal skills, Flexibility, Ability, Goal oriented, Judgment.

From the table 2 it is inferred that the demographic variable department has no significant inference on the factors like teamwork, reliability, responsibility, interpersonal relationship, interpersonal skills, flexibility, strategic thinking, fiscal responsibility, challenging formalities, goal oriented, standardization, quality of work, technical skills, ethical value, initiatives, ability and judgment. The demographic variable department has significant inference on the factors like communication.

\section{CONCLUSION}

The study is on the effectiveness of performance evaluation in the organisation shows that some improvisation have to be done with the present system. The present system used to measure the performance of the employees is still have to be improved by adding some more attributes. The identified attributes to be added with the present system is the individual leadership. The organisation is practicing many HR polices effectively. Since there are some area which is to be given more importance to be more effective.

Published By:

Blue Eyes Intelligence Engineering 
The management introduced the suggestion box system, which suggestion given by employees can be taken by the management effectively for implementation. The employees are the backbone of any organisation so effective analyse of the employees should be done.

\section{REFERENCES}

1. Wayne. F. Casino, (2010). Human Resource Management.

2. M. N. Mishra. (2012) Organisational Behaviour, Vikas Publishing House Pvt. Ltd., India.

3. Subba Rao, P. (2015). Personnel and Resource Management. Himalaya Publishing House, India.

\section{AUTHOR PROFILE}

S. Anitha, The author is currently working at Thiruthangal Nadar College, Chennai, Tamil Nadu as Assistant Professor. She completed her U.G., P.G and M.Phil at Madras University. Further she received her Ph.D from M.S University in Thirunelvelli. She has been publishing journals at National, International and UGC levels. She even participated and presented in many national and international conferences. Many FDPs were attended by her. She is familiar with marketing, HRM, Business management and Cost \& Management accounting and she produced $100 \%$ results in her subjects. She has been rendering her service for over 8 years as an Assistant Professor. 